\title{
On the front and at home: women in the modern Ottoman epic
}

\section{Can Eyüp Çekiç}

To cite this article: Can Eyüp Çekiç (2016) On the front and at home: women in the modern Ottoman epic, Middle Eastern Studies, 52:4, 623-639, DOI: 10.1080/00263206.2016.1178112

To link to this article: https://doi.org/10.1080/00263206.2016.1178112

曲 Published online: 27 May 2016.

Submit your article to this journal $₫$

Џll Article views: 168

Q View related articles $₫$

View Crossmark data 


\title{
On the front and at home: women in the modern Ottoman epic
}

\author{
Can Eyüp Çekiç
}

Department of History, Bilkent University, Ankara, Turkey

As a genre, Ottoman epic had flourished through the sixteenth century, when the empire was the most important Muslim power fighting against Christian powers. Traditionally, women had been largely excluded from Ottoman epic literature, which were narratives of the military campaigns and victories of prophets, heroic sultans and male ghazis, with women only entering into such epics tangentially, as part of the peoples defeated or conquered. However, in the nineteenth century, newly emerging literary forms, such as drama and the novel, enriched the epic themes in war literature, and new narrative methods encouraged writers of such epic war literature to create more dynamic female characters. But although such modern Ottoman epic literature did make use of female characters, they were made to act irrationally and emotionally in the narratives, regardless of their social status.

Women's presence in epic literature reveals the social transformation of gender roles in the late Ottoman Empire on three major axes. First, the evolution of women from being depicted as active participants on the military front to being portrayed as domestic figures is a noteworthy development that may be used to outline their changing social roles. The contradiction between being on the front and being at home thus represents the spatial and fictional status of women in modern Ottoman literature, whose writers were almost exclusively men. Second, the birth of active women characters in literature is a revealing way to understand Ottoman intellectuals' perception of the modern role of Ottoman Muslim women. Third, the literary trope of distinct spatial frameworks - i.e. stories taking place on the front and those taking place at home - imitates the patterns of social synchronization, and thus of nationalization, in late Ottoman society, as well as the increasingly prescribed roles for women. During this process, which can be followed in the literature, femininity generally came to be indicated through nervous breakdowns and weeping fits, or else through tropes of reproduction such as pregnancy and giving birth.

In particular, the emergence of the popular press in the last quarter of the nineteenth century helped the Hamidian regime to reconstruct gender roles and new responsibilities for women according to Ottoman and Muslim forms. ${ }^{1}$ The quest for an authentic Ottoman identity was part of a greater design into which members of Ottoman society were placed. Engin Akarlı separates the Hamidian Era from its predecessors in terms of its coherent interior, foreign and financial policies of resisting aggressive Western powers. ${ }^{2}$ In his

CONTACT Can Eyüp Çekiç caneyup@bilkent.edu.tr 
seminal work about Abdülhamid II's reign, Selim Deringil defines the late nineteenth-century effort by the Ottoman state as 'a process through which the legitimation ideology of the state is promoted and state policy is imposed on society'. ${ }^{3}$ This process involved the indoctrination of society through educational reforms. Benjamin Fortna addresses the ways in which moral norms were inserted into the curricula of newly founded schools according to this indoctrination process. ${ }^{4}$ In that sense, the Hamidian moral doctrine differs from the oppositional Young Ottoman movement's call for constitutionalism, liberties and emancipation by depending on a more comprehensive, officially supported scheme with social undertones.

This article explores the transformations within Ottoman social and political spheres in the last quarter of the nineteenth century in the light of their effect on female characters in modern Ottoman epic literature. It argues that the social projections of the autocratic reign of Abdülhamid II (r. 1876-1909) transformed the spatial position of women in modern Ottoman epic literature. At the same time, heroic female figures became domestic characters as the regime gradually rearranged the gender roles in Ottoman society. At the same time, the article also argues that the transformation of gender roles into a communitarian model, as promoted in the Hamidian regime, was not a clear-cut process, and can be deliberately related to larger developments in the spheres of social modernization and discipline. As Ottoman society evolved into a 'nation' whose members were increasingly concerned with the empire's problems, women in epic literature were reassigned to the sphere of domestic life, remade as guardians of the hinterland and caregivers for younger generations. The pro-natal demographic policies of the reform period (Tanzimat) contributed to the transformation of women's social roles, as, through reproduction and mothering, women's relationship with the modern state came to be constructed. ${ }^{5}$ This contract involved domestic, as opposed to public, obligations.

Overall, the participation of women in collective life in the Middle East has been limited by the roles assigned to women and to womanhood by the contemporary dominant political culture or cultures. In political terms, the impact of nationalism on the development of gender studies is evident. Interpreting the history of feminist studies in the Middle East, Deniz Kandiyoti suggests that the early phase of the debate was based on an effort to construct a relationship between cultural authenticity and Islam, with the early phase of postcolonial feminist writing denying that 'Islamic practices are necessarily oppressive or assert[ing] that oppressive practices are not necessarily Islamic'. ${ }^{6}$ Borrowing from Kandiyoti's interpretation of recent scholarship, it can be claimed that intellectuals of the reformist Tanzimat period, who defended the amelioration of women's status in Ottoman society, believed that the backward social status of Ottoman women was not determined by a socalled 'oppressive Islam'. Denying a correlation between women's status and Islamic precepts, these intellectuals claimed that Islam could offer an authentic standpoint for the reconstruction of women's social status, and that women's social status could be improved through an authentic interpretation of Islamic precepts. ${ }^{7}$

In this regard, the theme of female Muslim warriors appeared as a tool for responding to orientalists abroad and conservatives within the empire. Furthermore, women's presence in modern Ottoman epic may reveal certain social mechanisms that have been largely neglected in Middle East women's studies. On a structural basis, Islamic legal interventions and modern state practices regarding women's daily lives have recently been analysed by such scholars as J.E. Tucker, M.L. Meriwether, M.C. Zilfi and D. Kandiyoti. ${ }^{8}$ In 
particular, M.F. Hatem, and T. Demirci and S.A. Somel's works have shed light on an area of research into modern health policies and the reconstruction of Middle Eastern women's relationship with their body. ${ }^{9} \mathrm{~N}$. Sirman has emphasized the intricate dialogue between the emergence of nationalism and its interpretation of gender roles. ${ }^{10}$ Nevertheless, the modern transformation of gender roles demands an evaluation of the political attitudes within which femininity was redefined for specific political intentions. As is well known, particular historical moments and conditions produce common symbols that represent social transformation. For instance, Reynold and Humble's study on Victorian attitudes to femininity is a significant example of exposing how the ideological projections of a certain historical phase can be used to reconstruct the epistemology of gender roles. ${ }^{11}$ In line with this, this article also argues that the contradictions within which Ottoman heroines became domesticated in the modern Ottoman epic throughout the Hamidian Era can reveal not only intellectual, but also official projections of Ottoman women. Contemporary Islamist, patriotic and/or modernist views represent different but not distinct patterns, which produced a quasi-legal category for Ottoman women as regards their social responsibilities.

The birth of modern Ottoman theatre coincides with the Reform Edict (Islahat Fermanı) of 1856, when Sultan Abdülmecid promised equality to all of his subjects, regardless of faith or ethnicity. Even as the rights of minorities were thus defined in a legal statement, non-Muslim communities were engaging with Western forms of entertainment and expression through their easy access to cultural developments in Europe, and young members of the Armenian community in particular were ambitious to publicize modern theatre to the whole Ottoman community. At the same time, Muslim writers like Ali Bey, Ziya Paşa and Ahmed Vefik Efendi were writing and translating plays in increasing numbers during the 1870s. ${ }^{12}$

The Ottoman Armenian Agop Vartovian was among the first to expand the audience for drama, which he did by establishing a theatre in Fatih, one of Istanbul's historic districts in the Muslim part of the city, so as to reach a larger audience. On the night of 1 April 1873, the audience left Agop's famed establishment, the Ottoman Theatre (Osmanlı Tiyatrosu), with patriotic fervour, having just seen the political activist and reformer Namık Kemal's (1840-88) play Vatan yahud Silistre (The Motherland, or Silistra), which stirred public interest as early as its première. The audience celebrated the play's author by chanting, 'Long live Kemal, long live the motherland!' and among them were the leaders of the Young Ottomans, the foremost Muslim opposition movement who demanded a liberal constitutional regime in the Ottoman Empire.

Such patriotic propaganda disturbed the imperial administration. The next night, during the play's second performance, the police raided Agop's theatre. Soon afterward, the theatre was banned for a time, with Namık Kemal being arrested. Fearing dethronement, Sultan Abdülaziz (r. 1861-76) immediately issued a firman stating that, as Namık Kemal had published and distributed malicious publications, he needed to be sent away from Istanbul and disciplined. Within a month, and without a hearing, he and his Young Ottoman comrades were sent into exile to Famagusta in Cyprus. ${ }^{13}$

The Young Ottomans, who were part of the second bureaucratic generation of the Tanzimat Era, exploited the historical concept of meșveret (consultation) in order to make their political ideas legible to society. So as to better propagate modern Western political ideas regarding the source of government, the Young Ottoman Namık Kemal referred to the 
idea of the ummah, or community of Islam. The community elects the government, and the government implements the community's will on its behalf. ${ }^{14}$ Within this process, meşveret refers to representative government pertaining to $\mathrm{ijma}^{c}$, or consensus. ${ }^{15}$

Similarly, late Ottoman literature also reflects the revival of old political concepts in an attempt to propagate more modern liberal ideas insofar as such concepts were employed not only explicitly, but also through literary tropes. Historically, meşveret represented a social contract among political actors in the Islamic or Ottoman golden age. ${ }^{16}$ As the Young Ottomans saw it, every auspicious event to occur during those times had been the result of an agreement between parties, with the political and military decisions of the Ottoman golden age being made as part of a process of consensus. Namık Kemal took such Islamic concepts and reinvented them in order to match political developments in the West. The triumph of the will of the nation in political organization came to be seen as a potential solution for the empire's recent misfortunes. Such a political struggle, however, also demanded social reform, and the social status of women in particular became a vital issue and emerged as a major literary theme in the literature of the Tanzimat period. On the one hand, female characters were used to defend political ideas, while on the other hand, these characters directly reflected social changes in gender roles. Representations of femininity and womanhood altered in relation to developments in social discipline, social roles and social performance as regards communitarian politics.

Namık Kemal's play Vatan yahud Silistre (The Motherland, or Silistra) was the earliest work of modern Ottoman literature to reveal the profound exchange that existed between women's social roles and the security of the motherland. A few months before his exile, Namık Kemal used his column in the daily newspaper ibret to address a reform with the aim of reorganizing gender roles in family life in order to benefit the nation. ${ }^{17}$ In his view, personal desires and natural but nevertheless irrational emotions had to be bypassed for the needs of the vatan, the homeland. Therefore, even though Namık Kemal advocated women's emancipation, he insisted that free will was not more important than the national benefit. He was, for instance, an ardent opponent of abortion, claiming that women who had abortions 'ruined the wealth of the community and hurt the nation's decency'. $^{18}$

His outlook on these matters can be traced in Vatan yahud Silistre, which tells the story of a young girl named Zekiye who disguises herself as a man and follows her lover to the Balkan front to fight during the Russo-Turkish War of 1828-29. Zekiye, whose mother and younger brother died when she was young, is the daughter of an Ottoman officer who was wrongly accused and dismissed from the army and subsequently left his family in embarrassment, a theme resembling those seen in the nineteenth-century légion étrangère stories of European literature. ${ }^{19}$ Zekiye's ecstatic actions and adventures derive not from a patriotic motive, but rather from irrational, 'womanly' desires. On the front, she takes care of her lover, i̇lam, when he is wounded, and later she takes part in the dangerous mission to destroy an enemy arsenal only to be close to her beloved when the enemy surrounds the Ottoman castle at Silistra. Coincidentally, one of the commanders in the castle proves to be her lost father, so at the end of the war, Zekiye has both her father and her lover by her side. Her actions derive from her free will, which reunites her with the long-lost legitimate authority that her father represents. As a woman, this is the moment for her to remove her disguise, settle down and return to her real responsibility of creating a family and raising children to be of assistance to the motherland. 
Although the theme of women in disguise on the war front was typical enough in contemporary Western literature for Namık Kemal's play to sound familiar to Western ears, Vatan yahud Silistre was the first modern example in the Ottoman context to discuss gender roles in connection with patriotic endeavour, and the first Ottoman drama to patriotize femininity - in other words, it was the first Ottoman Joan-of-Arc story. ${ }^{20}$ In subsequent Ottoman literature, this theme became very popular, especially during the Balkan Wars (1912-1913) and the First World War. Within a few decades after Namık Kemal's play, the theme of such Joan-of-Arc stories eventually came to signify sacrificing one's life for the Ottoman motherland. ${ }^{21}$ However, what Namık Kemal accomplished through his play was to lessen the subversive effect of such a theme by making it subsidiary to patriotic romanticism, thereby to a certain extent equating 'love of the nation' with 'love of the other'. ${ }^{22}$ In the end, the theme of disguising one's gender comes to stand for a patriotic will that champions personal - and hence selfish - objectives.

In an analysis focusing on early modern English literature, Dianne Dugaw outlines a gender-based explication of fictional female warriors, pointing out how such characters require a detailed description of their costume, distinct behavioural characteristics for the opposite sexes, and specifically gendered relations between the heroine and the men around her. ${ }^{23}$ In Vatan yahud Silistre, however, the only detail given regarding Zekiye's costume is that it was a uniform that had belonged to her late brother. ${ }^{24}$ No one on the front suspects that she is a woman, and there is no mention of any sort of relationship with the men on the front except her (also unsuspecting) lover. The single argument that occurs between Zekiye and the men concerns her physical inability to engage in combat. Though she agrees with the men that she lacks the physical skills for fighting, for her, physical ability is not a prerequisite to dying, and the real aim is not to fight, but to die while performing patriotic deeds. ${ }^{25}$

In the end, then, the ability of the costume to veil a woman's sexuality becomes irrelevant. At the moment of disclosure, when Zekiye exposes herself as a woman, she easily shifts back to her identity as a lover and a daughter. In Dugaw's view, the heroine does not abandon her disguised sexual identity. ${ }^{26}$ Moreover, as was the case with his Western contemporaries, Namık Kemal designed his female character as androgynous, embodying both womanly behaviours and heroic acts. Unwomanly - and hence unnatural - roles were justified by the character's motivation of untainted, uncarnal love. Accordingly, Zekiye nurses islam when he is wounded and accompanies him on dangerous missions, despite the fact that he had so easily abandoned Zekiye to join the patriotic cause in the first place. Her genuine identity was preordained by islam when he tried to convince her to let him go and serve his motherland. According to him, he is 'a soldier at heart, while [she] is a mother by nature, wanted so as to raise soldiers for the motherland' ${ }^{27}$

As early as 1864, Ziya Pasha, a prominent writer of the Ottoman modernization period, published his Endülüs Tarihi (History of Andalusia) in order to call to mind not only the early Islamic and Arab world's military successes, but also its developments in the fields of science and culture. ${ }^{28}$ Such an invention, or reinvention, of Islamic tradition helped Ottoman intellectuals to speak back against the emerging orientalist approach of the Western academy. Moreover, Islamic revivalism offered supplementary themes to the late Ottoman cultural environment, encompassing its architectural, sartorial, pictorial, musical, poetical and theatrical products. 
A pioneering Tanzimat work on the history of Islam, Endülüs Tarihi directly inspired the use of themes from Islamic history in modern Ottoman literature. One of these was Abdülhak Hamid's (1851-1937) epic play Tarık yahud Endülüs Fethi (Tarık, or the Conquest of Andalusia), which is among the finest examples showing the intertextual dialogue that developed in the nineteenth-century Ottoman intellectual environment. Written in 1879, well before the Hamidian social policies were put into effect, this play manifestly reflects the ways in which the writing of history, as well as historical fiction, allowed an Ottoman intellectual to proliferate political thought.

Born into a bureaucratic family, Abdülhak Hamid's official career represents the largescale diplomatic challenge faced by the modern Ottoman Empire. In addition to posts in Georgia, Greece and Bombay, he served in the European capitals, such as Paris, London and Brussels. One of the most significant representatives of romanticism in modern Ottoman literature, he wrote numerous poems and plays during his long literary career, and Tarık - along with an Alexander romance called Eșber and another dealing with the story of Sardanapalus - is among his historical plays. ${ }^{29}$

In the preface to a 1919 edition of Tarık, Abdülhak Hamid emphasizes how he had written the play in Paris, a non-Muslim city, when Gazi Osman Pasha was in the Balkans and Gazi Ahmed Muhtar Pasha in the Caucasus, both fighting against the Russians. ${ }^{30}$ This not only describes the disturbance facing the empire, but also reminds the reader that the Ottoman state was still an empire, one spread out over a vast geography and able to fight on both eastern and western fronts very distant from the capital of Istanbul.

However, the empire should not be evaluated simply in terms of its material and military capacity. The Ottoman author wrote the play in Paris, the cultural capital of Western civilization in the nineteenth century, while the play itself takes place in Andalusia, well outside the Ottoman geography, and at the beginning of the eighth century, much earlier than the foundation of the Ottoman state. This geographical and historical distance helps the author to use literary tropes and ideological messages to construct and imply a convoluted function for the Ottoman Empire within the history of civilizations, its heritage and its modern prospects.

Based on the contrast between decadent Christian life and Muslim enthusiasm and morality, Tarık portrays Muslim conquests as efforts to rehabilitate a decadent world. For Abdülhak Hamid, 'lands under oppressors are meant to be conquered'. ${ }^{31}$ The Muslim army is depicted as being strictly disciplined so as to maintain civility and avoid cruelty, and because of this it is able to seize the heartland of the Christian world. ${ }^{32}$ In the play, the sieges of Christian castles in Iberia are shown as lasting a long time because Muslims believe that avoiding atrocities and bloodshed constitutes a service to humanity. ${ }^{33}$ One of the female ghazis in the Muslim army defines jihad as 'an obligation to give a lesson to the disobedient', and in her view this is beneficial for the following reasons:

[P]otentially disobedient nations become obedient by seeing another nation obeying through jihad, without bloodshed. If it is done to spread religion, jihad is acceptable. Because, when a religion spreads, war and hostility, lust and animosity, and the potential dangers of clashes between religions and sects disappear and an eternal peace prevails in the universe. ${ }^{34}$

In this way, Abdülhak Hamid justifies the Muslim agenda, portrays the rescue of a decadent world, and answers contemporary critics of Islamic civilization. 
In describing the conquests of Tariq ibn Ziyad on the Iberian Peninsula, Abdülhak Hamid refers to contemporary debates in the Ottoman Empire, one of which was the position of women in modern Ottoman society. The role of Muslim women during the spread of Islam is used as a theme to support the amelioration of women's status in the Ottoman world, a prominent subject in modern Ottoman literature, and for that reason the author portrays the Muslim army in Andalusia as a union of male and female warriors. Such an association of early Arab military enterprises in Andalusia with the modern struggle for women to take part in public life required a combination of various voices. In the play, whatever the historical and geographical distance of the setting might be from the time and place of composition, the political message is made to receive affirmation from men, women, and the Christian other, with the successes of Arab women being confirmed and propagated by individuals from both sides of the conflict. For instance, according to a Spanish convert who has taken the name Müslim and joined the Arab forces, it was the enhanced social position of Arab women that served as the underlying reason for the Arab advance. ${ }^{35}$ Initially finding the social status of Arab women peculiar, Müslim falls for a female Muslim warrior whom he deeply admires. His enthusiasm only deepens when the woman rejects his offer to protect her: unlike her European counterparts, she does not need protection. It is just this image of a powerful woman that attracts the convert. ${ }^{36}$

Besides this, Muslim women inform Müslim that love for one's nation takes precedence over love for another person. When the Christian convert Müslim then insists that one cannot fall for a nation, but only for a beautiful person, his beloved warns him that if he wants her to love him in return, he must love the nation more than he loves her. ${ }^{37}$ Thereby, the chivalric urges of the convert surrender to the wit of a female Muslim warrior. The physical superiority of men over women becomes insufficient for conducting a love affair. In other words, women's intellectual capacity and physical form have altered the previously asymmetrical relationship between the sexes.

Tarık, who witnesses the debate between the convert and the woman, delivers a speech addressing the correlation between the status of a nation and its women. For him, 'a nation's women determine its level of progress. A group of deteriorating women reveals the ignorance of a nation in educating its members'. ${ }^{38}$ Tarık then points out that, historically, women have been disadvantaged, with human societies being ruled by those who held authority. If those rulers would 'educate women as well as men and train them in military skills, I [Tarık] would be the student of a female teacher, and you [Müslim] would be a servant to an empress'. ${ }^{39}$

Tarık also depicts women's literacy as a prerequisite of an advanced society. In the play, Arab women are not only ghazis seeking glory for the religion, but also women of letters. ${ }^{40}$ Every female Muslim character in the play is represented as being just as literate and brave as a man, and they do not refrain from expressing their ideas among men. One of the play's subplots revolves around the romantic relationship between Tarık and Zehra, the daughter of Musa ibn Nusayr, the commander of the Andalusian conquests. Zehra is an archetype of an Arab woman who is both a warrior and educated. She pleads for the equal status of women within society, and in her view, both ghazu and literacy are Islamic provisions. As equal citizens of the Muslim nation, women are expected to observe these obligations, and in return they deserve respect from the male members of the community.

This portrayal of the advanced status of Muslim women encouraged Abdülhak Hamid to express his occidentalist outlook. Although Tarık was written in the cosmopolitan 
environment of nineteenth-century Paris, it was engaged with the premise of an ontological distinction between the Islamic world and the West, a distinction that the writer emphasizes through his portrayal of characters from the Christian court or of Western origin. These characters, surprised by how advanced Arab society is in this regard, cannot avoid comparing Muslim women to their Western counterparts. For example, while waiting for the approaching Arab army, some Christian lords discuss the differences between the conditions of women in both societies, agreeing that while Muslim women spill enemy blood for a religious cause, their counterparts in the Christian world pour wine, a symbol of moral inferiority and decay. ${ }^{41}$ In this way, the author makes male Christian soldiers unwittingly reinforce the image of the female ghazi by defining Christian women as representative of earthly pleasures.

The convert Muslim, in line with his European background, has difficulty understanding the status of women in his new environment. He questions the presence of women on the battlefield. One female Muslim warrior explores the sentiment of ethical superiority among Arab women. According to her, 'Women live and die as men do. They can be officers if not masters. Arab women do not appear in ballrooms or gardens, but in schools and on battlefields. They do not wear jewellery and fancy girdles, but swords and daggers. Because of that, they stroll through their enemy's palaces while others are besieged and enslaved'. ${ }^{42}$

Apart from its occidentalist aspects, the scene where the Christians are in the palace waiting for the Arab invaders is also used to examine the debate regarding the function of women in an army. There are rumours that women make up a quarter of the Arab army, and while some of the Christian characters in the court see this is as good news, others point out the difficulty of resisting a nation of which even the women take up arms. ${ }^{43}$ While these idle Christian men thus discuss the functions of womanhood, Muslim women proceed and continue to engage in heroic deeds, such as Zehra, who rescues her beloved Tarık from an attack and dresses his wounds.

According to Zehra, 'Tarık is not an army, not a castle, but a nation. ${ }^{44}$ Her love for the young commander is shown as equal to her love for the nation, and both require commitment and admiration. Nevertheless, as she fights beside Tarık, the young girl's aim is not only to save the nation, but also to take revenge, thereby exposing her feelings for him. ${ }^{45}$ Zehra's father Musa, Tarık's superior, is surprised to see how fragile and sensitive his warrior daughter is when she mentions the young man. ${ }^{46}$ Realizing the strength of her feelings, he promises Tarık his daughter if he can cross the strait onto the Iberian Peninsula. ${ }^{47}$ As news of Tarık's conquests begins to arrive, the young girl actively continues her heroic deeds, such as raising the flag of Islam above enemy castles. Salha, another female warrior with feelings for Tarık, accompanies Zehra on the front. This rivalry for Tarık is shown to be suppressed not only by military duties, but also by the moral injunction that a Muslim woman not openly expresses her emotions for a man. This is a border drawn not by religious precepts, but rather by an unwritten agreement between fellows. Abdülhak Hamid uses this issue of polygamy to reduce this friction between two Muslim women, who are depicted as naturally innocent. Zehra is ready to share her future husband with her friend. ${ }^{48}$ In one scene, the two young girls appear on the bell tower of a newly conquered town, standing with an imam performing the call to prayer. ${ }^{49}$ The future of their cause thus seems brighter than ever. 
Tarık, representing the alter ego of Abdülhak Hamid, leads the reader to better understand how the author evaluated gender issues. This legendary Muslim warrior fought in Andalusia against decadent enemies who were simply waiting in their courts to be enslaved. The author simultaneously attempts to remind his Ottoman countrymen of their historical successes and to inspire social reform, including the emancipation of women. Through Tarık's words concerning women's contribution to an advanced social organization, Abdülhak Hamid criticizes the backward status of women in the contemporary Ottoman world.

On the other hand, the warrior's personal relationships with women correspond to that of the author's. Although the play consistently shows an appreciation of women's role in the Muslim advance, the female characters remain weak vis-à-vis Tarık. For instance, both Zehra and Salha crave for Tarık's attention, peacefully noticing, appreciating and accepting each other's feelings while Tarık remains silent. The decision is only made when Salha dies. Tarık's silence on this death is based in his categorical superiority as the male protagonist, with his distance deriving from his moral superiority to something as mundane as romantic intrigue. In this way, emotions free the play's strong and literate female warriors from their masculine roles. Even so, however, they remain reasonable to the end, which is quite unlike the traditional correlation posited between emotions, the irrational and the female. $^{50}$

It is not clear whether Abdülhak Hamid defended polygamy or simply made use of it through historical distance to create dramatic excitement. The author's personal life, however, does offer a great deal of material towards an understanding of Tanzimat intellectuals' confusion regarding relations with women. They used the issue of the emancipation of women to question the traditional patriarchal social formation and archaic social conventions. However, at the same time their modern struggle against traditional norms was only operable through a compatibility with Islamic precepts. ${ }^{51}$ In the case of Abdülhak Hamid, the distance between his use of ancient references and pre-modern practices remains unclear. Abdülhak Hamid married four times, and never hesitated to keep mistresses while married. In his memoirs, he even justified his love life by asking a rhetorical question: 'The madam and the mistress help me by substituting for one another; why not love a rose and a hyacinth at one and the same time ${ }^{152}$

On the other hand, the female characters in Tarı are not simply the products of a happy male fantasy. Even though the author created them in order to propagate a more advanced social formation, these characters still object to, tease, surprise, irritate or deny the male characters. They carry swords and daggers, ride horses and salute the conquered towns. And they even approach Christian men and attempt to alter their views of women.

Overall, the liberated status of these female characters and their enthusiasms and passions reflect the vibrant political atmosphere of the 1870s. The theme of women on the front served as a metaphor for Ottoman intellectuals' demands for liberty. During the Hamidian era, however, every radical literary trope that might challenge patriarchal norms would disappear. In Duben and Behar's words, 'such passions were domesticated, repressed and channelled in socially acceptable ways'. ${ }^{53}$ Before long, the patriarchal Hamidian regime constituted its own understanding of gender roles in Ottoman society, and in the late Ottoman literature that followed the Hamidian social transformation, female role models changed. Warrior women got on their horses and rode away. Their descendants became domestic. 
Recent feminist scholarship on domestic and military spaces contributes to the literary representations of women in distinct spatial frameworks. Wars help to reconstruct spatial distinctions that separate women from a particular place and confine them in another. And war literature per se is 'highly gendered' ${ }^{\prime 54}$ and operates 'to figure a culture in which men fight while women remain at home preserving the domestic front'. ${ }^{55}$ In times of war, the front becomes 'wherever "women" are not'. ${ }^{56}$ This spatial construction refers not only to 'the limitation of women's mobility', but also to 'a social control on identity'. ${ }^{57}$ In her attempt to relate the fields of geography and gender, Doreen Massey pointed out that 'the construction of "home" as a woman's place has, moreover, carried through into those views of place itself as a source of stability, reliability, and authenticity'. ${ }^{58}$ In that sense, the spatialization of the dichotomy between masculinity and femininity in terms of 'battlefront and home-front helps to guarantee social stability'. ${ }^{59}$

In this regard, the Greco-Turkish War of 1897 provided Ottoman epic writers with the occasion to rearrange the spatial position of women according to the dichotomy between battlefront and homefront. One example of this is the most popular journalist and writer of the Hamidian Era, Ahmed Midhat (1844-1912) who, immediately after the war, published the novel Gönüllü. ${ }^{60}$ This work depicts the story of a volunteer, Recep Köso, originally from Larissa, who was among the Muslim Turks who abandoned their villages to Russian-backed Greeks following the withdrawal of the Ottoman troops in 1878. Two decades later, he finally finds a chance to claim back his fatherland and is voluntarily enlisted to march with the Ottoman army to the front. Upon the Ottoman victory, Recep Köso also rescues his beloved Philomene from her despotic husband, after which she converts to Islam and marries Recep.

It is exactly such adventure stories as Ahmed Midhat's Gönüllü, stories focusing on male soldiers on the front, that make up most late Ottoman war literature. Women only appear as passive figures, confined to their homes, objects that are to be saved and/or possessed. Nevertheless, in terms of the war literature of this period, the Greco-Turkish War of 1897 also represents the very first time that the everyday life of the families left behind by soldiers gone to the front became a topical focus. Given the recent boom in journalism, residents of the Ottoman capital of Istanbul were able to receive news from the front on a daily basis, and so warfare became a common concern. Reports from the battlefield were based mainly on a combination of epic literature and a discourse of masculinity. Nevertheless, the war also provided an opportunity to describe and advertise new gender roles. Domestic war experiences not only proposed new roles for women, but also reconstructed their social roles within the modern Ottoman community, as Ottoman women were linked up with the newly 'synchronized' Ottoman nation as their responsibilities to the empire as citizens began to emerge. While the gap between the domestic sphere and the front was sacrificed to patriotism, gender roles were distanced from one another and came to be rigorously defined: men were tasked with protecting the country, while the protection of the home became the foremost duty of women, whose weapons would be patience and purity.

For that purpose, manuals meant to educate Ottoman women regarding her domestic duties and etiquette books intended to train her concerning her social status and the appropriate behaviour began to be published. These popular books, manuals and journals were either directly translated from or inspired by their Western counterparts with similar social concerns, especially from the post-Civil War United States and Victorian Britain. One 
American manual, written by John Abbott in 1873 to educate mothers and called The Mother at Home, ${ }^{61}$ was translated into Ottoman Turkish in 1897 by the only female Muslim student at Istanbul's American College for Girls, Halide Edip, who would later become a significant political activist and a leader of the women's rights movement in Turkey, and who translated the book to convince a displeased Abdülhamid II to let her stay at the American college. Realizing the significance of the book for his policies, the sultan's reservations concerning the presence of a young Muslim woman at the college disappeared. The book became popular among soldiers' wives, especially during the height of the crisis with Greece. ${ }^{62}$ Its revenue was donated to the relief fund for the families of slain soldiers.

Called Mader (Mother) in Ottoman Turkish, the book had originally been written by Abbott to inform mothers about how to discipline children according to Christian norms. ${ }^{63}$ Its main argument is that early childhood education is significant for adult life, and that the best way to educate and discipline children is to teach them religious precepts. In her translation, Halide Edip transformed the Christian values into an Islamic framework. Thus, parenting and disciplining children became supported by Islam and tradition, akin to what the Hamidian regime set forth for the entire Ottoman society. Instilling gender roles on an everyday basis, together with the social education of women, became a major part of the general agenda. ${ }^{64}$ Nevertheless, in the late nineteenth-century Ottoman context, women's roles were primarily addressed in terms of the well-being of the nation and the community. As the empire was threatened by dissolution and occupation, the most decisive of these roles became mothers' raising of potential Ottoman soldiers within the family. Thereby, the relationship between women and the state was redefined, and threats to the empire's integrity helped the state to claim dominance over its female subjects.

The novel Asker Oğlu (Soldier's Son), written during the Greco-Turkish War of 1897 by the journalist Ahmed Rasim (1864-1932), is a prominent example describing the sentimental atmosphere and daily home life of ghazis, as well as in the capital. As described in the novel, when the Greeks took the offensive, 'Ottoman public opinion awoke. Red flags appeared everywhere. Accompanied by military bands, battalions came into Istanbul from all over Anatolia'. ${ }^{65}$ The tense atmosphere of the war gripped the capital and synchronized the reactions of the Ottoman community. Ahmed Rasim described the capital in the following manner:

This great city lost its tranquility, delightful monuments on the Bosphorus collapsed, the beams of light pouring from the houses became fewer, heavenly prayers emerged from the city's mosques, words of war were spoken in houses in place of words of humor, the old started to use compassionate words, women started to ask for help, the young developed signs of craziness, children started mimicking their siblings. The community seemed quite different. ${ }^{66}$

Asker O $\breve{g l u}$ tells the story of a young Ottoman lieutenant whose late father had also served in the Ottoman army. On a chilly April night, the young soldier gets off his horse and enters the courtyard of a shabby house in an old district of Istanbul. He has been ordered to leave his home, where he lives with his wife and his mother, to join the army against the Greeks. However, his first mission is to calm the worried women in the house.

His first encounter is with his young wife, who is waiting at the door with a kerosene lamp. At a glance, she knows what he has come there to tell them, and soon his mother 
joins, adding to the gloomy atmosphere. Now he stands like a castle between these two sentimental women: his role is to change the mood, and to that end he asks, 'Why have I become a soldier if not to serve the state in times of trouble? What did my father say when he signed me up for military school? Didn't he say to the school's director that he had brought the sultan another servant?' His mother then immediately remembers that her husband, seeing her crying once when he had been going off to the front, had said, 'these days are days of joy; crying suits none but the enemy'. ${ }^{67}$

As her son has thus reminded her of her patriotic duty, the mother, relieved, says, 'Your father should have been alive to see you! God bless his soul, who knows how happy he would be! ${ }^{68}$ Afterwards, the mother brings her son a janissary knife with which she girds her son while reciting the basmala. Next, she puts on his arm an armband inscribed with Qur'anic verses relating to conquest and says, 'Nobody can defeat you while you are wearing that', and it is at this point that the young soldier feels that the soul of his father is with him. Finally, she gives him some cotton and cloth to wrap any wounds he might receive. ${ }^{69}$

This ceremony of a soldier being girded for war by his mother signifies the role of women in bringing up soldiers for the sake of national well-being. The unbreakable bond between a soldier and his mother is significant in that it reproduces the same bond that exists between a soldier and his homeland. Replicating the maternal practices of the family, nurturing was to be performed for a soldier by the nation itself, with familial intimacy and devotion evolving into loyalty and sacrifice, a congenital transfer that ultimately facilitated the inhumane nature of military organization and discipline. Loyalty to the mother and the family became interchangeable with loyalty to the motherland and the nation. Masculine characteristics already consolidated by military performance became even more evident. Gender roles thus developed simultaneously around both motherhood and military service, equally significant patriotic concerns of the period.

In the novel, after this emotional ceremony, the ghazi leaves his home. In order to see him again, his mother and wife attend the official ceremony sending the army off from the Gulf of Izmit, near Istanbul. The ceremony begins with the crowd chanting 'Long live the sultan!' and singing the song 'O ghazis! The time to leave has come again for this poor one'. As Ahmed Rasim comments, 'the Ottomans go to war like they go to weddings'. ${ }^{70}$ As the ship leaves, prayers are heard from the minarets. As the 48th chapter of the Qur'an, alFath ('Victory' or 'Conquest'), is recited on the ship, the ghazi recalls his mother and his home as his late father's armband squeezes his arm. Ahmed Rasim points out that, at exactly the same time, his wife is also performing her own prayer, and so their souls are prostrating together. ${ }^{71}$

During the war, one day the mother takes her daughter-in-law to visit the tombs of saints in Istanbul, and they visit Eyüp Sultan and Zindan Kapısı to pray for the advance of the Ottoman army. ${ }^{72}$ The tomb of Eyüp Sultan, the Muslim saint and companion of the prophet Muhammad named Abu Ayyub al-Ansari, was built by Sultan Mehmed II after the conquest of Constantinople, and was a major sanctuary representing how the Ottomans related themselves to the older Byzantine capital, as here Mehmed refashioned an ancient sanctuary by building a tomb and a mosque in order to recall the significance of the city in Islamic history. ${ }^{73}$ In time, Eyüp Sultan came to serve as the final destination of the sultanic coronation ceremonies, and also as a popular spot for the city's residents to pray to God in times of both turmoil and felicity. The ghazi's mother and wife are among many others in Istanbul whose emotions and thoughts are synchronized for the well-being of the 
empire. These women's visits to sanctuaries stand not only for the continuation of, or sequel to, a traditional practice, but also for the invention of a community or a nation whose members are just as anxious as they regarding everyday politics. The salvation of the empire had become a widespread topic among commoners. Istanbul was under pressure due to migration from the occupied territories, and as a primary base for the army, it had been witnessing day-to-day developments on the front ever since the devastating Russo-Turkish War of $1877-78 .^{74}$ The city had already been fortified with strongholds, and evacuation plans had been made against any invasion attempt. Thanks to emerging media opportunities, its residents, as protectors of the hinterland, became more sensitive to developments on the front.

Ahmed Rasim's narration of the war's developments uses an epistolary style, with letters home from the ghazi informing the reader of what is going on at the front. Furthermore, through these letters, the author aims to emphasize the theme of love of the motherland. In one letter, for instance, the ghazi explains the mental state he is in by writing:

If there is any consolation for me, it is that I was invited to guard the motherland, which is the most compassionate mother of us all. I cannot be ungrateful. The love that I have for my mother is derived from the love that I have for my motherland. This love is so influential, so very poignant, that its goals are reason to sacrifice one's life. ${ }^{75}$

The sort of interchanging of love for another and love for the nation as pointed out by Nükhet Sirman in relation to Vatan yahud Silistre has been transformed, in Asker Oğlu, into the equalization of patriotic love and love for one's mother. The motherland, like the mother, is something to be grateful for, something to guard, and something that stands above all else.

Besides letters, Ahmed Rasim also uses the depiction of dreams to continue the dialogue between the soldier and his family. When communication with the front stops for a while, the women have numerous dreams, mainly based on the theme of salvation. One of the wife's dreams is especially remarkable: 'The ghazi in green clothes sat on the back of a green horse. The Qur'an was hung about his neck. He was speaking to a hodja in a large square. He saw his wife and kissed her hands. When he was asked what he had brought them, he answered, "The words of the Almighty"'. Ahmed Rasim interprets the dream by stating that 'the green symbolizes beneficence and sacrality; the horse symbolizes a swift journey; the words of the Almighty are the greatest felicity, the good news; the large square stands for relief'. ${ }^{76}$ A few days after this dream, the good news comes to Istanbul: the Ottoman army has won a quick victory, and the troops will be returning to the capital soon.

Following news of the victory, preparations begin to be made at home: the ghazi's mother and wife clean the house, buy new furniture, did personal care and prepare the ghazi's favourite meals. ${ }^{77}$ In the capital as a whole, and upon the order of the sultan, preparations are made for a grand welcoming ceremony. The military hospital at Gümüşsuyu is renovated, and hospitals and operating rooms are constructed at Yıldız, near Abdülhamid II's palace, so that the ghazis may 'be embraced by the sultan', the father of the Ottomans. $^{78}$

Over the two decades between the loss against Russia at the beginning of autocratic Hamidian rule and the war against Greece, the social change occurring can be observed 
through the changing connotations of the front and the home in the narratives. The last quarter of the nineteenth century witnessed extensive practices of modern social discipline and simultaneous developments in the Ottoman army. As the regime consolidated its patriarchal and communitarian ideology in every field of social life, gender roles were dissociated and redesignated. The contemporary Ottoman epic's main success derived from its ability to popularize certain political ideas, such as patriotism, imperialism and nationalism, as well as these ideals' social claims. The rich composition of late Ottoman epic literature reveals the social transformations being undergone in the concepts and practices of masculinity and femininity, and this composition is supported by these works' use of modern ideologies, political activism, and traditional and religious precepts. The continuities and changes observable in epic works based on female experiences also represent ideal female reactions to the empire's fate. Women, who were not a significant part of traditional Ottoman epic, became the centre of attention in the second half of the nineteenth century, and their awareness came to be attached to the imperial consciousness and to patriotic sensibilities. Accordingly, epic female characters and heroines started to emerge in the public sphere and to become involved in patriotic debates concerning the empire's fate. Such a metonymical use of women in epic literature aimed to diversify the domains of constitutional and liberal demands. It can be argued that women's presence on the front symbolized the active attitude adopted by early reformists in opposition to the establishment and its imposed authority. On the other hand, the growing authority of Sultan Abdülhamid II produced a different arrangement of the duties of women in warfare, which allows for further analysis of the regime's understanding of gender roles. In fin-de-siecle Ottoman literature, stories of women on the front disappeared and the heroines became wives and mothers. While protection of the Ottoman borders was reserved for male soldiers, women became guardians of the home and were tasked with securing future generations so as to satisfy the state's growing need for military manpower. Within this framework, the woman, the soldier, the capital, the sultan and the state were united. Nothing was set aside. The home became the front and the front became the home.

\section{Disclosure statement}

No potential conflict of interest was reported by the author.

\section{Notes}

1. E.B. Frierson, 'Mirrors Out, Mirrors In: Domestication and Rejection of the Foreign in LateOttoman Women's Magazines (1875-1908)', in F. Ruggles (ed.), Women, Patronage and Selfrepresentation in Islamic Societies (Albany: State University of New York Press, 2000), p.178. In 1895, a prominent women's journal of the era announced its role in its first issue 'as serving the Sultan and the Ottoman state by enabling women to become better mothers, better wives, and better Muslims'. Quoted in E.B. Frierson, 'Unimagined Communities: Women and Education in the Late-Ottoman Empire 1876-1909', Critical Matrix, Vol.9, No.2 (1995), p.72.

2. E.D. Akarlı, 'The Problems of External Pressures, Power Struggles, and Budgetary Deficits in Ottoman Politics Under Abdülhamid II (1876-1909)' (Ph.D. dissertation, Princeton University, 1976).

3. S. Deringil, The Well-Protected Domains: Ideology and the Legitimation of Power in the Ottoman Empire, 1876--1909 (London and New York: I.B. Tauris, 1998), p.10. 
4. See B.C. Fortna, 'Islamic Morality in Late Ottoman 'Secular' Schools', International Journal of Middle East Studies, Vol.32, No.3 (2000); B.C. Fortna, Imperial Classroom: Islam, the State, and Education in the Late Ottoman Empire (Oxford: Oxford University Press, 2002).

5. T. Demirci and S.A. Somel, 'Women's Bodies, Demography, and Public Health: Abortion Policy and Perspectives in the Ottoman Empire of the Nineteenth Century', Journal of the History of Sexuality, Vol.17 (2008), p.378.

6. D. Kandiyoti, 'Contemporary Feminist Scholarship and Middle East Studies', in D. Kandiyoti (ed.), Gendering the Middle East: Emerging Perspectives (New York: Syracuse University Press, 1996), p.9.

7. M.F. Hatem, 'Modernization, the State, and the Family in Middle East Women's Studies', in M.L. Meriwether and J.E. Tucker (eds.), Social History of Women \& Gender in the Modern Middle East (Boulder, CO, and Oxford: Westview Press, 1999), p.68. The nationalist writer Şemseddin Sami represented Islam as a catalyst for the emancipation of women, whom he considered responsible for the upbringing and education of younger generations. Ş. Sami, Kadınlar (İstanbul: Mihran Matbaası, 1296/1879), pp.54-60. Ahmed Rıza, a leader of the next generation of the Young Turks, blamed Abdülhamid II's regime for the backward status of women, employing Islamic precepts to claim that rising up against the despotic regime was a national obligation for Ottoman women. A. Rıza, Vazife ve Mes'uliyyet: Kadın (Paris: Osmanlı ittihat ve Terakki Cemiyeti, 1324/1908), pp.49-51.

8. See J.E. Tucker, In the House of the Law: Gender and Islamic Law in Ottoman Syria and Palestine (Berkeley, CA: University of California Press, 1998); M.L. Meriwether and J.E. Tucker (eds.), Social History of Women \& Gender; M.C. Zilfi (ed.), Women in the Ottoman Empire: Middle Eastern Women in the Early Modern Era (Leiden, New York, Köln: Brill, 1997); D. Kandiyoti (ed.), Women, Islam, and the State (London: MacMillan, 1991).

9. See M.F. Hatem, 'Modernization, the State, and the Family'; M.F. Hatem, 'The Professionalization of Health and the Control of Women's Bodies as Modern Governmentalities in Nineteenth Century Egypt', in Women in the Ottoman Empire; Demirci and Somel, 'Women's Bodies'.

10. See N. Sirman, 'Gender Construction and Nationalist Discourse: Dethroning the Father in the Early Turkish Novel', in F. Acar and A. Güneş-Ayata (eds.), Gender and Identity Construction: Women of Central Asia, the Caucasus and Turkey (Leiden, Boston, MA, Köln: Brill, 1999).

11. K. Reynolds and N. Humble, Victorian Heroines: Representations of Femininity in NineteenthCentury Literature and Art (Hemel Hempstead: Harvester Wheatsheaf, 1993).

12. Nevertheless, theatres were operated mainly by non-Muslims, and the actors were non-Muslims as well, partly because Muslim women were not allowed to take part in public shows. On the other hand, however, the presence of Armenian women on the stage also attracted harsh criticism from the religious authorities of the Armenian community. See N. Menemencioğlu, 'The Ottoman Theatre 1839-1923', Bulletin (British Society for Middle Eastern Studies), Vol.10, No.1 (1983), p.52.

13. R. Ahmet, Yakın Çağlarda Türk Tiyatrosu Tarihi (i̇stanbul: Kanaat Kütüphanesi, 1934), p.36.

14. S.. Mardin, The Genesis of Young Ottoman Thought (Princeton, NJ: Princeton University Press, 1962), p.294.

15. Ibid., p.309.

16. Ibid., p.134.

17. N. Kemal, 'Aile', ibret (18 Ramazan 1289/19 November 1872).

18. Demirci and Somel, 'Women's Bodies', pp.406, 411.

19. A.H. Tanpınar, XIX. Asır Türk Edebiyatı Tarihi (istanbul: YKY, 2006), p.345.

20. The theme of women warriors disguising themselves in men's clothing dates to a very early period in Turkish literature, and to Persian literature before that. However, such examples, like the romance Hurşid u Ferahşâd (1387), were quite different in that they were far from expressing patriotic urges. See N. Tezcan, 'Divan Edebiyatında Aşk, Kadın Kahramanlar ve Kıyafet Değiștirme Motifi', Acta Turcica, Vol.4, No.2 (2012), pp.114-16; N. Külekçi, XI-XX Yüzyıllar EI Yazması Metinler ve Özetleriyle Mesnevi Edebiyatı Antolojisi (Erzurum: Aktif Yayınevi, 1999), pp.246-49.

21. For a list of late Ottoman Joan-of-Arc stories, see Z. Toprak, 'Osmanlı́nın Dört Jeanne d'Arc'ı: 'Karıların Sahibkıranı Jan Dark", Toplumsal Tarih, Vol.13, No.75 (2000), pp.4-10; also see Z. 
Toprak, Türkiye'de Kadın Özgürlügü ve Feminizm (1908-1935) (Istanbul: Tarih Vakfı Yurt Yayınları, 2015), p.106.

22. N. Sirman, 'Gender Construction and Nationalist Discourse', p.163.

23. D. Dugaw, Warrior Women and Popular Balladry, 1650-1850 (Cambridge: Cambridge University Press, 1989), pp.148-51.

24. N. Kemal, Vatan yahud Silistre (Istanbul: 1289/1873), p.42.

25. Ibid., p.58.

26. Dugaw, Warrior Women, p.153.

27. Kemal, Vatan, pp.27-8.

28. Z. Paşa, Endülüs Tarihi (Dersaadet: Takvimhane-i Amire, 1276-80/1859-64), p.5.

29. For a detailed assessment of Abdülhak Hamid's literary career, see P. de Bruijn, The Two Worlds of Eşber: Western Orientated Verse Drama and Ottoman Turkish Poetry by 'Abdülhakk Hamid (Tarhan) (Leiden: Research School CNWS, 1997).

30. A. Hamid, Tarık yahud Endülüs Fethi (Istanbul: Matbaa-i Amire, 1335/1919), p.3.

31. A. Hamid, Tarık yahud Endülüs Fethi, 1st ed. (İstanbul: 1296/1879), p.87. Hereafter, it is this first edition that will be cited.

32. Ibid., pp.56-7.

33. Ibid., p.93.

34. Ibid., pp.99-100.

35. Ibid., p.74.

36. Ibid., p.76.

37. Ibid., p.77.

38. Ibid., p.58.

39. Ibid., pp.58-59.

40. Ibid., pp.9-10.

41. Ibid., p.36.

42. Ibid., pp.70-72.

43. Ibid., p.35.

44. Ibid., p.13.

45. Ibid., pp.12-13.

46. Ibid., pp.18-20.

47. Ibid., pp.28-30.

48. Ibid., p.150.

49. Ibid., p.82.

50. A.M. Jaggar, 'Love and Knowledge: Emotion in Feminist Epistemology', Inquiry: An Interdisciplinary Journal of Philosophy, Vol.32 (1989), p.151.

51. Kandiyoti, 'End of Empire', p.26.

52. i. Enginün (ed.), Abdülhak Hamid'in Hatıraları (Istanbul: Dergah Yayınları, 1994), p.306.

53. A. Duben and C. Behar, Istanbul Households: Marriage, Family and Fertility, 1880-1940 (Cambridge: Cambridge University Press, 1991), p.88.

54. M.R. Higonnet, 'Cassandra's Question: Do Women Write War Novels?' in M.R. Higonnet (ed.), Borderwork: Feminist Engagements with Comparative Literature (Ithaca, NY, and London: Cornell University Press, 1994), p.144.

55. H.M. Cooper and A. Munich, 'Introduction', in M. Squier (eds.), Arms and the Woman: War, Gender, and Literary Representation (Chapel Hill, NC, and London: The University of North Carolina Press, 1989), p.xiii.

56. C. Enloe, Does Khaki Become You? The Militarization of Women's Lives (London: Pluto, 1983), p.15. Also quoted in D.R. Cohen, Remapping the Home Front: Locating Citizenship in British Women's Great War Fiction (Boston, MA: Northeastern University Press, 2002), p.1.

57. D. Massey, Space, Place and Gender (Cambridge: Polity Press, 1994), p.179.

58. Ibid., p.180.

59. M.R. Higonnet, 'Introduction', in J. Jenson, S. Michel and M.C. Weitz (eds.), Behind the Lines: Gender and Two World Wars (New Haven and London: Yale University Press, 1987), pp.1.

60. A. Midhat, Gönüllü: Milli Roman (İstanbul, Kırkanbar Matbaası, 1897). 
61. J.S.C. Abbott, The Mother at Home; or, The Principles of Maternal Duty Familiarly Illustrated (New York: Harper \& Brothers Publishers, 1873). The Mother at Home was based on Abbott's The Christian Mother, which was published as early as 1833 .

62. Toprak, Feminizm, p.209. Later, in her 1925 memoir, Halide Edip condemned the Hamidian regime as a despotic lapse in Islamic history. According to her, 'the wonderful Islamic democracy, based on the people's choice of great and idealistic leaders, full of humanity and common sense, became an Asiatic despotism of dynasties'. Quoted in E. Thompson, Justice Interrupted (Cambridge, MA: Harvard University Press, 2013), p.97.

63. J.S.C. Abbott, Mâder, translated by Halide Edip (Dersaadet: Karabet Matbaası, 1314/1897). For a brief commentary on Halide Edip's attraction to Protestant Christian views of motherhood, see B. Reeves-Ellington, 'Constantinople Woman's College: Constructing Gendered, Religious, and Political Identities in an American Institution in the Late Ottoman Empire', Women's History Review, Vol.24, No.1 (2015), p.62.

64. Several manuals were published to educate women for their domestic duties according to Islamic-communitarian values in the later Hamidian Era. See, for instance, F. Aliye, Levâyih-i Hayat (İstanbul: Hanımlara Mahsus Gazete Matbaası, 1315/1897); H. Remzi, Mirât-ül Beyt: Hanımlara Yâdigar (İstanbul: Arakel Matbaası 1316/1898); Nazım, İslam Hanımlarına Mahsus Fennî ve Ahlâki Mektublar (Konstantiniye: Kitaphâne-i İslam ve Askerî 1316/1898).

65. A. Rasim, Asker Oğ/u (Kostantiniye: Malumat Matbaası 1315/1897), p.4.

66. Ibid., pp.5-6.

67. Ibid., pp.14-15. This scene is reminiscent of the occurrence depicted in the painting Oath of the Horatii (1784) by Jacques-Louis David.

68. Ibid., p.17.

69. Ibid., pp.21-2.

70. Ibid., p.85.

71. Ibid., p.36.

72. Ibid., p.40.

73. For the discovery of the grave of Ayyub al-Ansari and the construction of the monumental tomb on the sanctuary by Mehmed II, see Ç. Kafesçioğlu, Constantinopolis/Istanbul: Cultural Encounter, Imperial Vision, and the Construction of the Ottoman Capital (University Park: Pennsylvania State University Press, 2009), pp.45-52.

74. For an analysis of the political orientation of the Hamidian regime and the shifting demographic structure of the empire after the losses in the Balkans and the Caucasus, see K. Karpat, 'The Hijra from Russia and the Balkans: The Process of Self-definition in the Late Ottoman State', in D.F. Eickelman and J. Piscatori (eds.), Muslim Travellers: Pilgrimage, Migration, and the Religious Imagination (London: Routledge, 1990), pp.137-46. Demirci and Somel argues that the devastation of the war against Russia encouraged Abdülhamid II to combine pro-natal practices with the strengthening of disciplinary measures. See Demirci and Somel, 'Women's Bodies', p.402.

75. Rasim, Asker Oğlu, p.43.

76. Ibid., p.91.

77. Ibid., pp.91-4.

78. Ibid., p.97. 